$$
\begin{aligned}
& \text { 강진만 패류생산해역의 위생학적 안전성 평가연구 } \\
& \text { 박큰바위·조미라·권지 영 }{ }^{1} \cdot \text { 손광태 }^{1} \cdot \text { 이두석 }{ }^{1} \text { - 이희정* } \\
& \text { 국립수산과학원 남서해수산연구소 } \\
& \text { 1국립수산과학원 식품안전과 }
\end{aligned}
$$

\title{
Evaluation of the Bacteriological Safety of the Shellfish-growing Area in Gangjinman, Korea
}

\author{
Kunbawui Park, Mi Ra Jo, Ji Young Kwon'1, Kwang Tea Son¹, \\ Doo Seog Lee ${ }^{1}$ and Hee Jung Lee* \\ Southwest Sea Fisheries Research Institute, NFRDI, Yeosu 556-823, Korea \\ ${ }^{1}$ Food Safety Research Division, NFRDI, Busan 619-705, Korea
}

The sanitary quality of a shellfish-growing area in Gangjinman, Korea, was assessed through a bacteriological examination of seawater form January 2007 to December 2009. The range of the geometric mean (GM) and the estimated 90th percentile for most-probable-number (MPN) values for fecal coliforms in samples collected in the designated area were 2.0-2.4 and 6.1-11.5 MPN/100 mL, respectively. Therefore, the bacteriological quality of seawater in the designated area in the Gangjinman area met the National Shellfish Sanitation Program (NSSP, USA) guidelines for approved areas. Also, the sanitary status of shellfish harvested from the designated area met the Korean Shellfish Sanitation Program (KSSP) fecal coliform criterion $(<230$ MPN/100 g). However, the degree of bacteriological contamination increased rapidly, and water quality exceeded the criteria for approved areas when large amounts of rain fell before the sampling date. Fortunately, fecal pollutants did not affect the bacteriological quality of a buffer zone established between the shoreline and the designated area. These results indicate that the current buffer zone established around the designated area protects the designated area properly.

Key words: Designated area, Fecal coliform, Gangjinman areas, Shellfish growing area

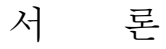

남해 강진만은 경상남도의 남서부에 위치한 연안해역으로, 남해군, 사천시, 하동군에 의해 둘러싸여 있는 반폐쇄성 내만 이며, 평균수심은 $3.6 \mathrm{~m}$ 로 주로 생산되는 패류는 굴, 피조개 등이다. 패류는 연안해역에서 주로 서식하며 이동성이 거의 없고, 여과섭이 활동을 통하여 먹이를 섭취한다. 이러한 패류 의 특성 때문에 해수 중에 부유하는 병원성세균 및 바이러스 등과 같은 위해물질들이 쉽게 체내에 축적이 이루어짐으로 (Cliver, 1988; Grimes, 1991) 오염된 패류의 섭취로 인한 식중 독 사고 사례는 오래전부터 많이 보고가 되어 있다 (Feldhusen, 2000; Potasman et al., 2002). 또한 패류는 병원성세균의 인간환경-인간의 순환의 매개체가 되기도 하기 때문에 (Legnani et al., 1998) 패류의 위생안전성 확보를 위해서는 서식지의 위생관리가 대단히 중요하여 미국과 유럽연합 등 선진국에서 는 패류생산해역의 위생상태에 따라 등급을 부여하여 관리하 고 있다. 미국에서는 National Shellfish Sanitation Program (NSSP)에 준하여 해수 중의 분변계대장균 (fecal coliform)의 수에 따라 허가해역 (Approved area), 제한해역 (Restricted area), 금지해역 (Prohibited area) 및 폐쇄해역 (Closed area) 등으로 구분하며, 각 등급해역 사이에는 조건부 해역을 두고

\footnotetext{
*Corresponding author: hjlee111@nfrdi.go.kr
}

있다 (U.S. FDA, 2007). 또 유럽연합에서는 날것으로 섭취할 수 있는 이매패류, 극피류, 피낭류 및 복족류의 미생물 기준으 로 대장균 (Escherichia coli) $230 \mathrm{MPN} / 100 \mathrm{~g}$ 이하, Salmonella $25 \mathrm{~g}$ 중 음성으로 규정하고 있다 (European Commission, 2005). 이러한 패류 생산해역의 위생조사 연구는 최근 국민들의 관심 이 높아지고 있는 식품 안전성 확보를 위해서 가장 중요한 것이 해산물의 경우 생산 해역에서의 위생 안전성 평가이다. $\mathrm{NSSP}$ 규정에 의해 조사가 진행이 되어 설정된 조사해역에서 의 위생안전성 평가는 향후 안정적으로 패류생산해역의 위생 관리를 실시하기 위한 아주 중요한 자료이다.

우리나라에서도 패류를 외국에 수출하기 위하여 패류가 많이 생산되는 연안해역에 대하여 위생조사를 실시한 후 위생 기준에 부합하는 수역을 수출용 패류생산 지정해역(이하 지 정해역)으로 설정하여 관리하고 있다 (Kim, 1975; kwon et al., 2007; Ha et al., 2009; Shim et al., 2009). 경남 남해군에 위치한 강진만 해역은 굴과 피조개 양식이 성행하고 있으며 이 해역에서 생산되는 패류의 수출을 지원하기 위하여 2000년 1월부터 실시한 위생조사 결과를 근거로 2004년 3월에 조사면 적 8,000 ha 중 5,290 ha에 대하여 수출용 패류생산해역 (제7호 해역)으로 지정하여 관리하고 있다. 그러나 연안해역에 위치 한 지정해역은 육지와 인접해 있어 육상에서 유입되는 오염원 의 영향을 받을 수 있으며 최근 인구증가 및 산업 발달로 


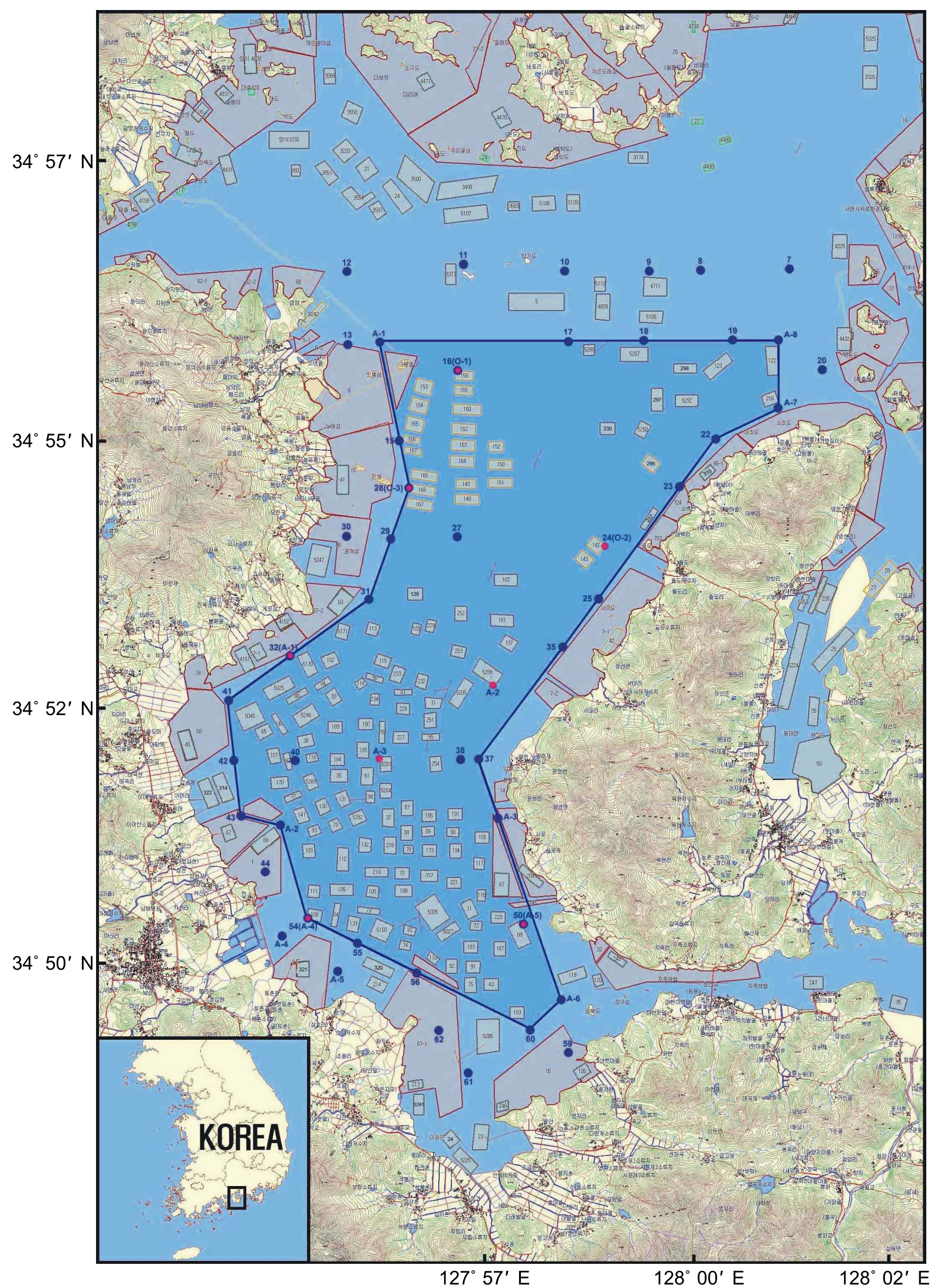

Fig. 1. Sampling stations for sanitary survey of shellfish growing area in Gangjinman, Korea. 
인하여 오염물질 발생량도 크게 증가하여 패류의 안전성을 크게 위협하는 요인으로 지적되고 있으며 (Lipp and Rose, 1997), 또한 낚시 등 여가활동 인구의 증가로 인하여 분변을 비롯한 오염물질이 해역으로 유입될 우려가 있어 본 연구에서 는 강진만 해역에서 생산되는 패류의 위생학적 안전성을 확보 와 육상에서 유입되는 오염물질의 영향을 최소화하기 위하여 설정되어 있는 완충해역이 적절하게 설정되어 있는지를 재평 가하고, 또한 최근 3년간 (2007년 2009년) 실시한 위생조사 결과가 우리나라 및 미국의 패류생산해역 관리기준에 부합하 는지를 조사하였다. 또한 이 결과는 향후, 육상에서 발생하는 오염원 (공장 오폐수, 생활하수 및 축산 분뇨 등)에 의한 조사 해역의 위생 안전성 답보를 위한 중요한 자료로 사용될 것으 로 기대된다.

\section{재료 및 방법}

\section{조사지점 및 시료채취}

강진만 해역은 경상남도 남해군과 남해군 창선도 그리고 북쪽으로는 하동군 및 사천시에 둘러싸여 있는 반폐쇄성 내만 으로 수역면적 약 $80 \mathrm{~km}^{2}$ 이다. 강진만 해역 위생조사를 위한 조사지점은 오염원, 지형적 여건, 해류유동상태 등을 고려하 여 47 개의 해수지점과 8 개소의 패류채취지점을 각각 설정하 여 매월 1회씩 총 36회에 걸쳐 시료를 채취하였다 (Fig. 1.). 해수는 표층용 채수기를 이용하여 수면에서 약 $10 \mathrm{~cm}$ 깊이에 서 멸균된 유리병에 채수하였으며, 굴은 수하연의 상층, 중층, 하층의 각 1 개 부착기를 채취, 피조개는 잠수하여 채취하였다. 채취한 패류는 멸균된 황동솔로 부착물 등을 제거한 후 물기 를 제거하고 멸균된 용기에 담았다. 모든 시료는 $10^{\circ} \mathrm{C}$ 이하로 유지하여 실험실로 운반한 후 즉시 실험에 사용하였다.

\section{실험방법}

해수의 수온과 염분은 수질분석기 (YSI 556MPS, YSI Life Science, USA)를 사용하여 현장에서 측정하고 염분은 $\mathrm{psu}$ (practical salinity unit)로 나타내었다. 해수 및 패류시료에 대한 대장균군, 분변계대장균 및 생균수 시험은 Recommended Procedure for the Examination of Sea Water and Shellfish (APHA, 1970)에 준하였다. 즉, 해수와 패류의 대장균군 및 분변계대장균 함량은 각 희석단별로 5 개 시험관을 사용하는 최확수법 (Most Probable Number, MPN)으로 측정하고, 그 결과는 MPN/100 mL (또는 $100 \mathrm{~g}$ )으로 표시하였다. 생균수는 standard plate count agar (Difco, Becton Drive, USA)를 사용하 여 $35 \pm 0.5^{\circ} \mathrm{C}$ 에서 48 시간 배양하여 나타난 집락의 수로 표기하 였다. 그리고 패류시료에 대한 대장균 (E. coli) 시험은 유럽연
합 (European Commission, 2005)의 규정에 의거 ISO/TS 16649-3 (ISO, 2005)의 방법에 따라 최확수법으로 실시하였다.

해수 및 패류의 위생학적 평가

각 조사지점의 패류생산해역으로서의 안전성은 미국 NSSP 에서 규정하는 허가해역의 세균학적 수질기준에 준하여 평가 하였다 (US FDA, 2007). 즉, 각 조사지점별로 3년간 총 36회의 분변계대장균 분석결과를 활용하여 '기하평균치 $14 \mathrm{MPN} / 100$ $\mathrm{mL}$ 을 초과하지 않고, 계산된 90번째 백분위수 (the estimated 90th percentile, 이하 90th percentile로 표기)가 $43 \mathrm{MPN} / 100$ $\mathrm{mL}$ 이하'의 기준에 부합하는 지를 평가하였다. 이 때 90th percentile 값은 다음과 같은 방법으로 계산하였다.

Est. 90th $=$ Antilog $[(\mathrm{S} \log ) 1.28+\mathrm{X} \log ]$

$\mathrm{Slog}=$ 각 자료 그룹에서 각각의 $\mathrm{MPN}$ 의 대수값의 표준편차 $\mathrm{X} \log =$ 각 자료 그룹에서 각각의 $\mathrm{MPN}$ 의 대수값의 평균

한편, 조사해역 내 서식하는 패류의 안전평가는 유럽연합 에서 규정하는 패류 중 $E . c o l i$ 함량에 따른 패류생산해역의 등급기준 즉, $\mathrm{A}$ 등급 $(230 \mathrm{MPN} / 100 \mathrm{~g}), \mathrm{B}$ 등급 $(4,600 \mathrm{MPN} / 100$ $\mathrm{g})$ 및 $\mathrm{C}$ 등급 $(46,000 \mathrm{MPN} / 100 \mathrm{~g})$ 을 적용하여 비교하였다 (European Commission, 2004, 2005).

\section{결과 및 고찰}

해수의 일반적 성상

강진만 해역의 조사기간 동안 월별 평균수온 및 평균염분의 변화는 Fig. 2에 나타내었다. 해수의 평균수온 범위는 6.21 $26.72^{\circ} \mathrm{C}$ 으로 1 월이 가장 낮았고, 8 월이 가장 높았다. 염분의 범위는 24.39 33.39 psu이었으며 태풍과 강우가 많았던 9월에 가장 낮았으며 5 월에 가장 높은 것으로 확인되었다.

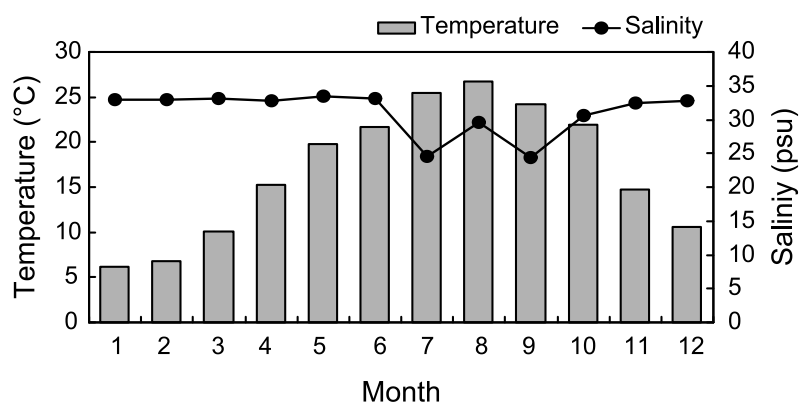

Fig. 2. Monthly variation in temperature and salinity for seawater in Gangjinman from 2007 to 2009.

Table 1. Results of the bacteriological examinations of seawater in the designated and adjacent area in Gangjinman from 2007 to 2009

\begin{tabular}{|c|c|c|c|c|c|c|c|c|c|c|c|}
\hline \multirow{3}{*}{ Section } & \multicolumn{10}{|c|}{ per $100 \mathrm{~mL}$} & \multirow{3}{*}{$\begin{array}{l}\text { No of } \\
\text { samples }\end{array}$} \\
\hline & \multicolumn{5}{|c|}{ Total coliform } & \multicolumn{5}{|c|}{ Fecal coliform } & \\
\hline & Range & $\mathrm{GM}^{1}$ & $90 \mathrm{th}^{2}$ & No. & $\%$ & Range & GM & 90th & & $\%$ & \\
\hline Designated area & $<1.8 \sim 9,200$ & $2.3 \sim 3.0$ & $9.1 \sim 24.3$ & 36 & 3.1 & $<1.8 \sim 2,400$ & $2.0 \sim 2.4$ & $6.1 \sim 11.5$ & 35 & 3.0 & 1,152 \\
\hline Adjacent area & $<1.8 \sim 5,400$ & $2.4 \sim 4.9$ & $11 \sim 43.6$ & 23 & 4.3 & $<1.8 \sim 2,400$ & 2.0 2.8 & $5.9 \sim 16.7$ & 20 & 3.7 & 540 \\
\hline
\end{tabular}


Table 2. Results of the bacteriological examinations of seawater in the designated area in Gangjinman from 2007 to 2009

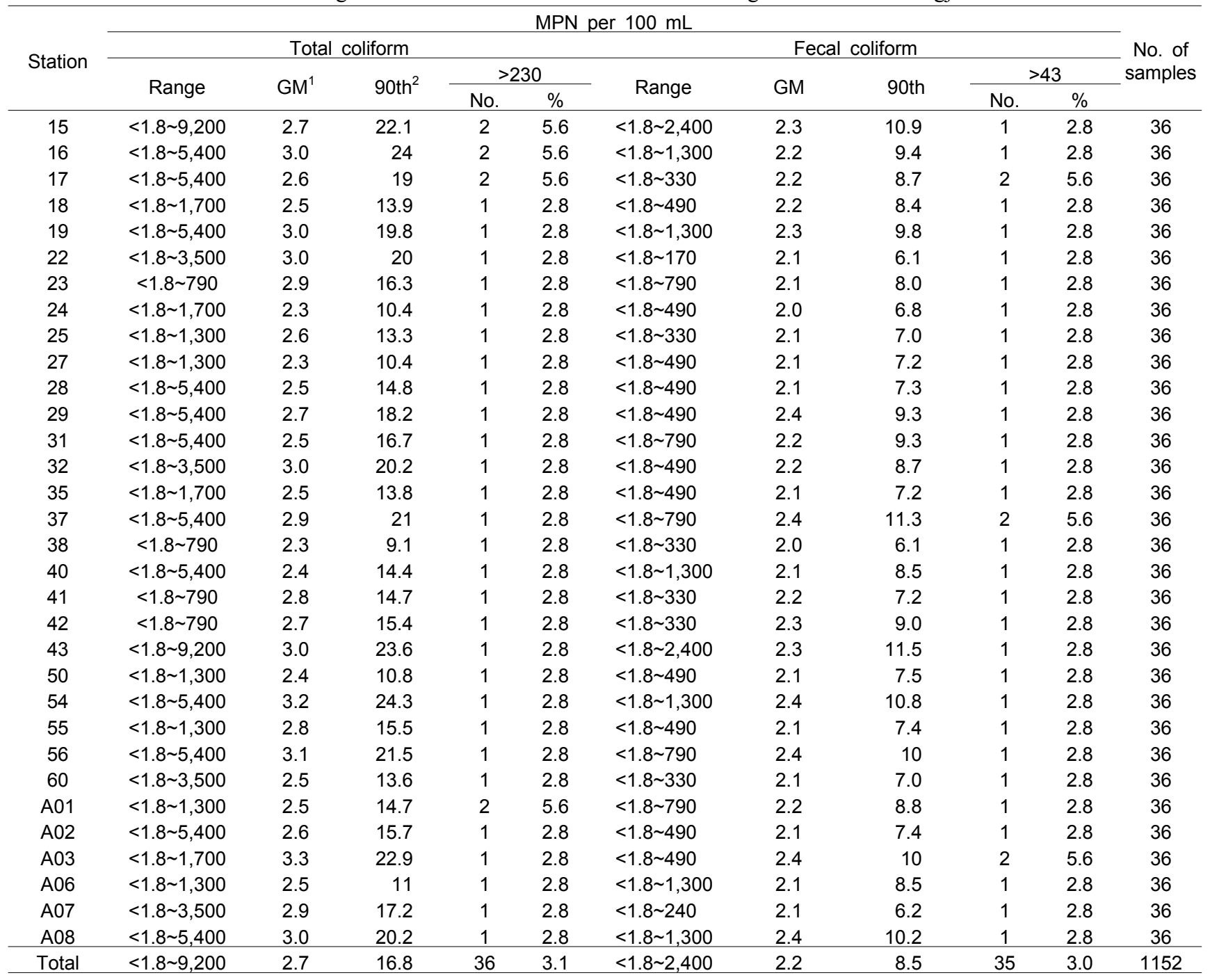

${ }^{1} \mathrm{GM}$, Geometric Mean.

${ }^{2} 90$ th, The estimated 90 th percentile.

지정해역 및 주변해역 해수의 위생학적 성상

지정해역 및 주변해역 해수에 대한 대장균군 및 분변계대장 균 수의 범위, 분변계대장균 수의 기하학적 평균치와 90th percentile 값을 Table 1에 나타내었다.

지정해역 내에 위치한 32 개 조사지점에서 대장균군과 분변 계대장균 수의 범위는 각각 $<1.8 \sim 9,200 \mathrm{MPN} / 100 \mathrm{~mL}$ 및 $<1.8$ 2,400 MPN/100 mL이었으며, 분변계대장균 수의 기하학 적 평균치와 90th percentile 값의 범위는 각각 2.0 2.4 MPN/100 $\mathrm{mL}, 6.1$ 11.5 MPN/100 mL으로 나타났다. 따라서 지정해역내 해수는 수산물품질관리법의 지정해역 수질기준과 미국의 허 가해역 수질기준에서 제시하고 있는 분변계대장균 수의 기하 학적 평균치가 $14 \mathrm{MPN} / 100 \mathrm{~mL}$ 이하이고, 90th percentile 값이 $43 \mathrm{MPN} / 100 \mathrm{~mL}$ 이하의 관리규정에 부합하는 것으로 나타났 다 (MOMAF, 2002; US FDA, 2007).
주변해역에 위치한 15 개 조사지점에서 대장균군과 분변계 대장균 수의 범위는 각각 $<1.8 \sim 5,400 \mathrm{MPN} / 100 \mathrm{~mL}$ 및 $<1.8 \sim 2,400 \mathrm{MPN} / 100 \mathrm{~mL}$ 이었으며, 분변계대장균 수의 기하학 적 평균치와 90th percentile 값의 범위는 각각 $2.0 \sim 2.8 \mathrm{MPN} / 100$ $\mathrm{mL}, 5.9$ 16.7 MPN/100 mL으로 주변해역에서도 지정해역의 세균학적 수질기준에 부합하는 것으로 나타났으나 90th percentile 값이 지정해역 해수보다 높은 것으로 보아 육상에 인접한 지점에서는 오염원의 영향을 받는 것으로 사료된다.

\section{조사지점별 해수의 세균학적 수질평가}

강진만 해역에 인접한 배수유역에서 발생하는 오염원이 해역에 어떠한 영향을 미치는지를 알아보기 위하여 3 년간 (총36회)의 조사결과를 근거로 처리한 각 조사지점별 기하학 적 평균치 및 90th percentile 값을 Table 2 및 Table 3 에 나타내 었다. 
Table 3. Results of the bacteriological examinations of seawater in the adjacent area in Gangjinman from 2007 to 2009

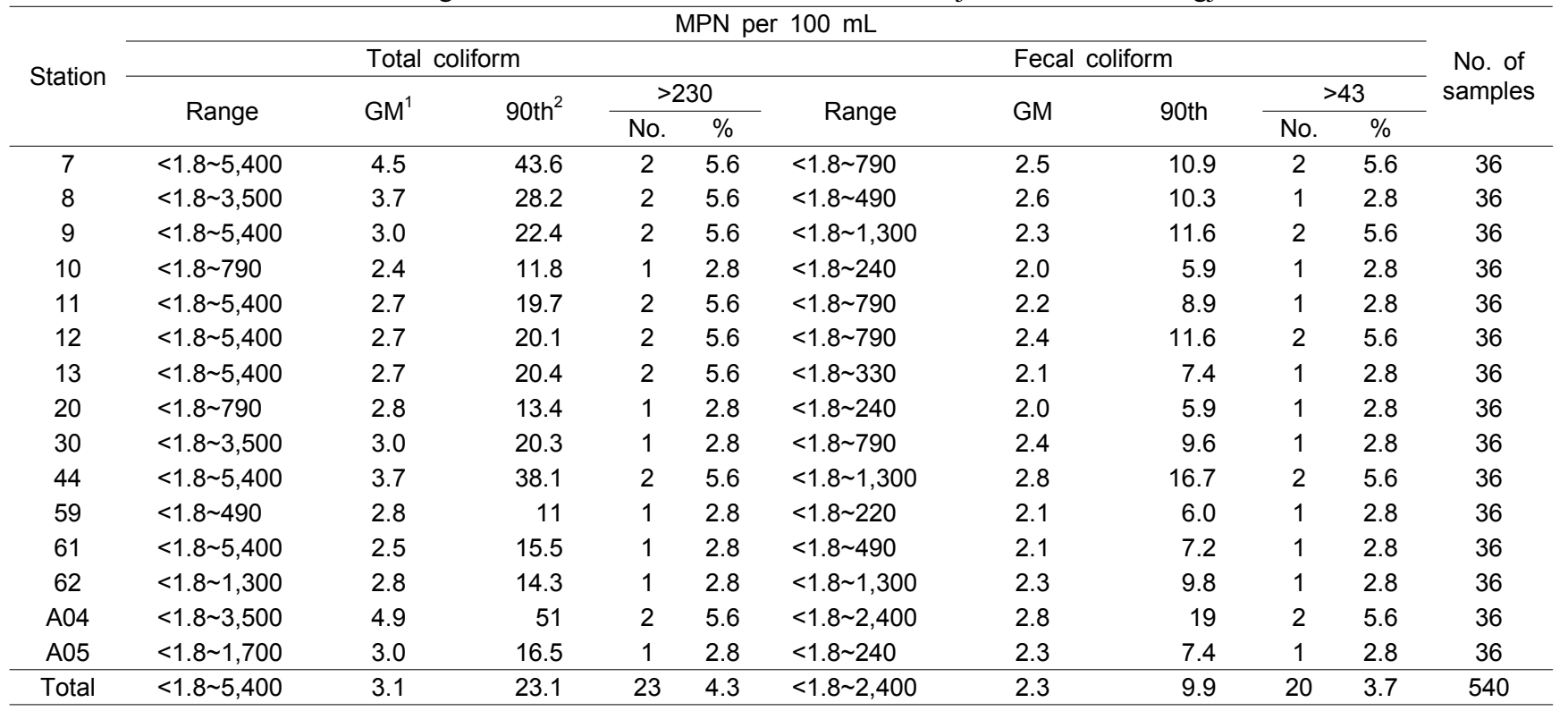

${ }^{1} \mathrm{GM}$, Geometric Mean.

${ }^{2} 90$ th, The estimated 90 th percentile.

Table 4. Monthly variation of bacteriological water quality in Gangjinman from 2007 to 2009

\begin{tabular}{|c|c|c|c|c|c|c|c|c|c|c|c|c|}
\hline \multirow{4}{*}{ Station } & \multirow{4}{*}{ Month } & \multicolumn{10}{|c|}{ MPN per $100 \mathrm{~mL}$} & \multirow{4}{*}{$\begin{array}{l}\text { No. of } \\
\text { samples }\end{array}$} \\
\hline & & \multirow{3}{*}{ Range } & \multicolumn{4}{|c|}{ Total coliform } & \multicolumn{5}{|c|}{ Fecal coliform } & \\
\hline & & & \multirow{2}{*}{$\mathrm{GM}^{1}$} & \multirow{2}{*}{$90 \mathrm{th}^{2}$} & \multicolumn{2}{|c|}{$>230$} & \multirow{2}{*}{ Range } & \multirow{2}{*}{ GM } & \multirow{2}{*}{ 90th } & \multicolumn{2}{|c|}{$>43$} & \\
\hline & & & & & No. & $\%$ & & & & No. & $\%$ & \\
\hline \multirow{12}{*}{ Designated area } & 1 & $<1.8 \sim 6.1$ & 1.8 & 2.5 & 0 & 0.0 & $<1.8 \sim 2.0$ & $<1.8$ & 1.8 & 0 & 0.0 & 96 \\
\hline & 2 & $<1.8 \sim 2.0$ & $<1.8$ & 1.8 & 0 & 0.0 & $<1.8 \sim<1.8$ & $<1.8$ & $<1.8$ & 0 & 0.0 & 96 \\
\hline & 3 & $<1.8 \sim 13$ & 1.9 & 2.9 & 0 & 0.0 & $<1.8 \sim 2.0$ & $<1.8$ & 1.8 & 0 & 0.0 & 96 \\
\hline & 4 & $<1.8 \sim 13$ & 2.2 & 4.2 & 0 & 0.0 & $<1.8 \sim 4.5$ & 1.8 & 2.1 & 0 & 0.0 & 96 \\
\hline & 5 & $<1.8 \sim 11$ & $<1.8$ & 2.2 & 0 & 0.0 & $<1.8 \sim 11$ & $<1.8$ & 2.2 & 0 & 0.0 & 96 \\
\hline & 6 & $<1.8 \sim 7.8$ & 1.8 & 2.4 & 0 & 0.0 & $<1.8 \sim 2.0$ & $<1.8$ & 1.8 & 0 & 0.0 & 96 \\
\hline & 7 & $<1.8 \sim 240$ & 8.2 & 60.3 & 3 & 3.1 & $<1.8 \sim 79$ & 3.4 & 12.7 & 3 & 3.1 & 96 \\
\hline & 8 & $<1.8 \sim 79$ & 3.3 & 11.9 & 0 & 0.0 & $<1.8 \sim 22$ & 2.1 & 4.1 & 0 & 0.0 & 96 \\
\hline & 9 & $<1.8 \sim 9,200$ & 22 & $1,948.8$ & 33 & 34.4 & $<1.8 \sim 2,400$ & 12.3 & 447.1 & 32 & 33.3 & 96 \\
\hline & 10 & $<1.8 \sim 7.8$ & 1.8 & 2.6 & 0 & 0.0 & $<1.8 \sim 4.5$ & 1.8 & 2.3 & 0 & 0.0 & 96 \\
\hline & 11 & $<1.8 \sim 7.8$ & 2.0 & 3.3 & 0 & 0.0 & $<1.8 \sim 4.5$ & 1.8 & 2.1 & 0 & 0.0 & 96 \\
\hline & 12 & $<1.8 \sim 4.0$ & 1.8 & 2.0 & 0 & 0.0 & $<1.8 \sim 2.0$ & $<1.8$ & 1.8 & 0 & 0.0 & 96 \\
\hline \multirow{12}{*}{ Adjacent area } & 1 & $<1.8 \sim 12$ & 2.1 & 3.9 & 0 & 0.0 & $<1.8 \sim 4.5$ & $<1.8$ & 2.1 & 0 & 0.0 & 45 \\
\hline & 2 & $<1.8 \sim 4.5$ & 1.8 & 2.3 & 0 & 0.0 & $<1.8 \sim 2.0$ & $<1.8$ & 1.8 & 0 & 0.0 & 45 \\
\hline & 3 & $<1.8 \sim 11$ & 2.1 & 3.9 & 0 & 0.0 & $<1.8 \sim 4.0$ & 1.8 & 2.1 & 0 & 0.0 & 45 \\
\hline & 4 & $<1.8 \sim 41$ & 3.1 & 10.2 & 0 & 0.0 & $<1.8 \sim 6.1$ & 1.9 & 2.8 & 0 & 0.0 & 45 \\
\hline & 5 & $<1.8 \sim 4.5$ & 1.8 & 2.5 & 0 & 0.0 & $<1.8 \sim 2.0$ & $<1.8$ & 1.8 & 0 & 0.0 & 45 \\
\hline & 6 & $<1.8 \sim 13$ & 1.9 & 3.1 & 0 & 0.0 & $<1.8 \sim 7.8$ & 1.8 & 2.7 & 0 & 0.0 & 45 \\
\hline & 7 & $<1.8 \sim 2,400$ & 11.7 & 167.2 & 8 & 17.8 & $<1.8 \sim 2,400$ & 4.4 & 34.4 & 5 & 11.1 & 45 \\
\hline & 8 & $<1.8 \sim 79$ & 4.0 & 17.1 & 0 & 0.0 & $<1.8 \sim 33$ & 2.4 & 6.1 & 0 & 0.0 & 45 \\
\hline & 9 & $<1.8 \sim 5,400$ & 24.9 & $2,065.9$ & 15 & 33.3 & $<1.8 \sim 1,300$ & 12.3 & 402.5 & 15 & 33.3 & 45 \\
\hline & 10 & $<1.8 \sim 7.8$ & 2.0 & 3.1 & 0 & 0.0 & $<1.8 \sim 4.5$ & 1.8 & 2.1 & 0 & 0.0 & 45 \\
\hline & 11 & $<1.8 \sim 13$ & 1.9 & 3.0 & 0 & 0.0 & $<1.8 \sim 4.5$ & 1.8 & 2.2 & 0 & 0.0 & 45 \\
\hline & 12 & $<1.8 \sim 6.8$ & 1.9 & 2.9 & 0 & 0.0 & $<1.8 \sim 2.0$ & $<1.8$ & 1.8 & 0 & 0.0 & 45 \\
\hline
\end{tabular}

${ }^{1} \mathrm{GM}$, Geometric Mean.

${ }^{2} 90$ th, The estimated 90 th percentile. 
조사지점 중 90th percentile 값이 가장 높은 지점은 주변해역 에 위치한 A-4번 지점이며 분변계대장균수의 90th percentile 값이 $19 \mathrm{MPN} / 100 \mathrm{~mL}$ 으로 나타났다. A-4번 지점은 남해군 남해읍에 위치한 봉천 수문과 약 $400 \mathrm{~m}$ 떨어져 있어 해역으로 유입되는 오염원의 영향을 쉽게 받고 있는 것으로 나타났으나 봉천 수문과 약 $850 \mathrm{~m}$ 떨어져 있는 54번 지점에서 분변계대장 균수의 90th percentile 값이 $10.8 \mathrm{MPN} / 100 \mathrm{~mL}$ 으로 나타난 것으로 보아 지정해역과 봉천 수문 사이에 설정되어 있는 완충해역 때문에 지정해역에 미치는 영향이 미비한 것으로 보여진다.

남해군 남해읍 동산천 유역에서 방출되는 오염원은 최종방 출지점으로부터 $700 \mathrm{~m}$ 떨어진 44번 지점에서 분변계대장균수 의 90th percentile 값이 $16.7 \mathrm{MPN} / 100 \mathrm{~mL}$ 으로 지정해역 수질 기준을 초과하지는 않았지만 다른 지점들 보다는 90th percentile 값이 높게 나타나 동산천 유역에서 방출되는 오염원 의 영향을 받고 있는 것으로 확인되었으나 $1.2 \mathrm{~km}$ 떨어진 A-2번 지점에서 90th percentile 값이 $7.4 \mathrm{MPN} / 100 \mathrm{~mL}$ 으로 안정적인 수질상태를 유지하고 있었다.

지정해역 경계선에 위치한 37번 지점에서 분변계대장균수 의 90th percentile 값이 $11.3 \mathrm{MPN} / 100 \mathrm{~mL}$ 으로 지정해역 내에 위치한 32 개 조사지점 중에서 가장 높게 나타내었다. 이는 조사지점이 남해군 창선면 광천마을로부터 약 $500 \mathrm{~m}$ 떨어진 곳에 위치하여 육상에서 유입되는 오염원의 영향을 받았기 때문으로 추정된다.

Ha et al. (2009)은 한산.거제만해역 패류양식장에 대한 세균 학적 위생안전성 평가 연구에서 주변해역 조사지점 중 분변계 대장균수의 90th percentile 값이 기준치인 $43 \mathrm{MPN} / 100 \mathrm{~mL}$ 를 초과하여 검출된 지점으로 간덕천 수문에서 $1 \mathrm{~km}$ 거리에 위치 하고 있는 23 번 지점과 둔덕천 방류지점과 $0.5 \mathrm{~km}$ 거리에 위치하고 있는 32 번 지점으로 육상과 인접한 지점에서 기준치 를 초과하여 검출되었으나 지정해역 주변에 설정되어 있는 완충해역이 지정해역 수질을 보호하는데 적절하게 설정되어 있다고 평가하였으며 Kwon et al. (2007)은 가막만에 대한 세균학적 안전성평가에서 여수항과, 선소 인근의 해수에서 342.2 3,270 MPN/100 mL 90th percentile 값으로 검출되었으 나 각 오염원으로부터 3 4 km 떨어진 조사지점에서는 미국의 허가해역 기준에 부합하였다고 보고하였다. 이상의 결과로 보아 패류생산해역의 안전성 확보하기 위해서는 육상에서 유입되는 오염물질을 희석시킬 수 있는 완충해역이 생산해역 과 오염원 사이에 확보되어야 하며, 또한 완충해역 범위의 오염물질의 유입량에 따라 달라질 것으로 판단된다.

\section{월별 해수의 위생학적 성상}

조사기간 동안 월별 해수의 위생지표세균 변화를 Table 4에 나타내었다. 해수의 월별 대장균군 및 분변계대장균수의 범위는 각각 <1.8 9,200 MPN/100 mL 및 <1.8 2,400 MPN/100 $\mathrm{mL}$ 으로 나타났으며 특히 7월과 9월에 높게 나타났다.

지정해역 해수에서 분변계대장균수가 $43 \mathrm{MPN} / 100 \mathrm{~mL}$ 을 초과하는 시료는 9월에 32 개 (33.3\%)로 가장 많았으며, 7월에
는 3 개 $(3.1 \%)$ 시료에서만 기준치를 초과하여 검출되었으며 이 시기를 제외한 다른 시기에는 기준치를 초과하여 검출된 시료는 없었다. 주변해역 해수에서도 지정해역 해수와 동일하 게 9월에 15 개 $(33.3 \%)$ 로 가장 많이 초과하여 검출되었으며 다음으로는 7월에 5개 (11.1\%)로 나타났다. 이는 2007년 9월과 2009년 7월에 조사 전 많은 강우로 인하여 육상에서 기인한 오염물질들이 해역으로 유입되어 강진만 해역 해수의 수질이 악화된 것으로 사료되며 비록 조사 전 강우는 없었지만 2008 년 7월에 지정해역 해수 37번 및 A-3번 지점에서 기준치를 초과하여 검출되었는데 이는 하천과 인접한 지점으로 하천에 서 방출되는 오염원의 영향을 받은 것으로 추정된다.

Kwon et al. (2007)이 가막만 패류생산해역에 대한 위생학적 평가에서 지정해역내 해수의 분변계대장균수가 $43 \mathrm{MPN} / 100$ $\mathrm{mL}$ 을 초과하는 시료는 강우가 집중되는 하절기인 7월과 9월, Song et al. (2008)은 충남 태안해역에 대한 계절별 위생조사 결과 해수의 위생지표세균 함량은 7월에 가장 높았으며 분변 계대장균 $43 \mathrm{MPN} / 100 \mathrm{~mL}$ 을 초과하는 시료도 겨울철에 비하 여 여름철에 훨씬 많았다고, Ha et al. (2009)도 한산·거제만해 역에서 7월에 강우의 영향으로 지정해역 해수에서는 14 개 시료가 주변해역 해수에서는 25 개 시료가 각각 기준치를 초과 하여 검출되었다고 보고하였다. 또한 Shim et al. (2009)도 자란 만 - 사량도 해역에 대한 월별 위생학적 평가결과 7월부터 10 월 사이의 여름철에 다소 높은 균수를 나타내었다고 보고하 여 강우가 많은 하절기에 해수의 위생지표세균의 오염도가 높아지는 것과 동일한 경향을 나타내었다. 이상의 결과로 보 아 강우 발생에 따른 오염물질 유입량이 강진만 해역의 위생 학적 성상에 가장 큰 영향을 미치는 요인으로 판단된다.

\section{패류의 위생학적 성상}

강진만 해역에 서식하는 패류의 세균학적 안전성은 유럽연 합의 Commission Regulation (EC) No 2073/2005 (European Commission, 2005) 및 Regulation (EC) No 854/2004 (European Commission, 2004)에 따라 평가하였다. 이들 규정에 따르면 패류 중 E. coli의 함량이 $230 \mathrm{MPN} / 100 \mathrm{~g}$ 이하이면 $\mathrm{A}$ 등급 해역에 해당되어 수확 후 즉시 섭취(생식)가 가능하다. 그리고 시료의 $90 \%$ 에서 $E . c o l i$ 가 $\leq 4,600 \mathrm{MPN} / 100 \mathrm{~g}$ 인 B등급 해역, 또는 $\leq 46,000 \mathrm{MPN} / 100 \mathrm{~g}$ 인 C등급 해역으로 규정하고 있다.

강진만 해역에서 생산된 굴의 수확은 일반적으로 11 월부터 다음해 3 월까지 지속된다. 지정해역 내에 위치하고 있는 3 개 조사지점 $(\mathrm{O}-1, \mathrm{O}-2, \mathrm{O}-3)$ 에서 채취한 굴의 분변계대장균수 및 생균수의 범위는 각각 $<18 \sim 20 \mathrm{MPN} / 100 \mathrm{~g}$ 및 90 1,500 $\mathrm{CFU} / \mathrm{g}$ 으로 분변계대장균과 생균수의 기준에 부합하는 것으 로 나타났다 (Table 5).

5 개 조사지점 (A-1, A-2, A-3, A-4, A-5)에서 채취한 피조개 의 분변계대장균수 및 생균수의 범위는 각각 < $18 \sim 490$ $\mathrm{MPN} / 100 \mathrm{~g}$ 및 $30 \sim 6,000 \mathrm{CFU} / \mathrm{g}$ 이었으며 54개 중 2개 시료 $(2.2 \%)$ 가 분변계대장균수의 기준치를 초과 한 것으로 나타났 다 (Table 5). 2007년 9월과 2009년 7월에 발생한 강우의 영향 으로 기준치를 초과하였으며 이는 해수와 동일한 결과를 나타 내었다. Kwon et al. (2007)도 가막만 해역에서 생산된 굴 시료 
Table 5. Results of the bacteriological examinations of oyster and ark shell collected in the designated area in Gangjinman from 2007 to 2009

\begin{tabular}{|c|c|c|c|c|c|c|c|c|c|c|c|c|}
\hline \multirow{4}{*}{ Area } & \multirow{4}{*}{ Station } & \multicolumn{8}{|c|}{ MPM per $100 \mathrm{~g}$} & \multirow{2}{*}{\multicolumn{2}{|c|}{ Viable cell count/g }} & \multirow{4}{*}{$\begin{array}{l}\text { No. of } \\
\text { samples }\end{array}$} \\
\hline & & \multirow{3}{*}{ Range } & \multicolumn{3}{|c|}{ ecal coliform } & \multicolumn{4}{|c|}{ Escherichia coli } & & & \\
\hline & & & $\mathrm{GM}^{1}$ & & & Range & GM & & & \multirow{2}{*}{ Range } & \multirow{2}{*}{ GM } & \\
\hline & & & $G|V|$ & No. & $\%$ & Range & GIVI & No. & $\%$ & & & \\
\hline \multirow{10}{*}{$\begin{array}{c}\text { Designated } \\
\text { Area }\end{array}$} & $0-1$ & $<18 \sim 20$ & 19 & 0 & 0.0 & $<18 \sim 40$ & 19 & 0 & 0.0 & $210 \sim 1,000$ & 478.1 & 12 \\
\hline & O-2 & $<18 \sim 20$ & 20.1 & 0 & 0.0 & $<18 \sim 20$ & 20.1 & 0 & 0.0 & $150 \sim 1,500$ & 522.1 & 8 \\
\hline & O-3 & $<18 \sim 20$ & 19.3 & 0 & 0.0 & $<18 \sim 20$ & 19.3 & 0 & 0.0 & $90 \sim 1,000$ & 421 & 9 \\
\hline & Total & $<18 \sim 20$ & 19.5 & 0 & 0.0 & $<18 \sim 40$ & 19.5 & 0 & 0.0 & $90 \sim 1,500$ & 473.8 & 29 \\
\hline & $A-1$ & $<18 \sim 20$ & 21.4 & 0 & 0.0 & $<18 \sim<18$ & 21.4 & 0 & 0.0 & $400 \sim 5,000$ & 1414.2 & 2 \\
\hline & A-2 & $<18 \sim 18$ & $<18$ & 0 & 0.0 & $<18 \sim 18$ & $<18$ & 0 & 0.0 & $90 \sim 500$ & 184.7 & 3 \\
\hline & A-3 & $<18 \sim 490$ & 68.2 & 1 & 7.1 & $<18 \sim 310$ & 68.2 & 1 & 7.1 & $160 \sim 4,800$ & 483.6 & 14 \\
\hline & A-4 & $<18 \sim 330$ & 56.5 & 1 & 3.8 & $<18 \sim 200$ & 56.5 & 0 & 0.0 & $30 \sim 6,000$ & 399 & 26 \\
\hline & A-5 & $<18 \sim 170$ & 59.3 & 0 & 0.0 & $<18 \sim 40$ & 59.3 & 0 & 0.0 & $200 \sim 900$ & 428.6 & 9 \\
\hline & Total & $<18 \sim 490$ & 44.5 & 2 & 2.2 & $<18 \sim 310$ & 44.5 & 1 & 1.4 & $30 \sim 6,000$ & 582 & 54 \\
\hline
\end{tabular}

${ }^{1} \mathrm{GM}$, Geometric Mean.

Table 6. Effect of rainfall amount and time on the bacteriological quality of seawater in Gangjinman from 2007 to 2009

\begin{tabular}{|c|c|c|c|c|c|c|c|c|c|c|c|c|c|}
\hline \multirow{4}{*}{$\begin{array}{l}\text { Rainfall } \\
\text { date }\end{array}$} & \multirow{4}{*}{$\begin{array}{c}\text { Rainfall } \\
\text { amount } \\
(\mathrm{mm})\end{array}$} & \multirow{4}{*}{$\begin{array}{l}\text { Sampling } \\
\text { date }\end{array}$} & \multicolumn{10}{|c|}{ MPN per $100 \mathrm{~mL}$} & \multirow{4}{*}{$\begin{array}{l}\text { No. o } \\
\text { sampl } \\
-\quad \text { es }\end{array}$} \\
\hline & & & \multirow{3}{*}{ Range } & \multicolumn{4}{|c|}{ Total coliform } & \multicolumn{5}{|c|}{ Fecal coliform } & \\
\hline & & & & \multirow{2}{*}{$\mathrm{GM}^{1}$} & \multirow{2}{*}{$90 \mathrm{th}^{2}$} & \multicolumn{2}{|c|}{$>230$} & \multirow{2}{*}{ Range } & \multirow{2}{*}{ GM } & \multirow{2}{*}{ 90th } & \multicolumn{2}{|c|}{$>43$} & \\
\hline & & & & & & No. & $\%$ & & & & No. & $\%$ & \\
\hline 2007.04 .16 & 23.0 & 2007.04 .18 & $<1.8 \sim 13$ & 2.6 & 5.9 & 0 & 0.0 & $<1.8 \sim 4.0$ & 1.8 & 2.2 & 0 & 0.0 & 32 \\
\hline 2007.07.09 & 41.0 & \multirow{2}{*}{ 2007.07.11 } & \multirow{2}{*}{$<1.8 \sim 130$} & \multirow{2}{*}{7.1} & \multirow{2}{*}{42.6} & \multirow{2}{*}{0} & \multirow{2}{*}{0.0} & \multirow{2}{*}{$<1.8 \sim 33$} & \multirow{2}{*}{4.7} & \multirow{2}{*}{18.6} & \multirow{2}{*}{0} & \multirow{2}{*}{0.0} & \multirow{2}{*}{32} \\
\hline 2007.07.10 & 37.0 & & & & & & & & & & & & \\
\hline 2007.09 .14 & 22.0 & \multirow{3}{*}{2007.09 .18} & \multirow{3}{*}{$790 \sim 9,200$} & \multirow{3}{*}{$2,755.9$} & \multirow{3}{*}{$7,532.8$} & \multirow{3}{*}{32} & \multirow{3}{*}{100} & \multirow{3}{*}{$170 \sim 2,400$} & & & & & \\
\hline 2007.09 .15 & 76.0 & & & & & & & & 615.1 & $1,440.7$ & 32 & 100 & 32 \\
\hline 2007.09.16 & 91.5 & & & & & & & & & & & & \\
\hline 2008.01 .11 & 12.0 & 2008114 & $<18 \sim 61$ & 21 & 35 & 0 & 0.0 & $<18 \sim 20$ & $<18$ & 18 & 0 & 00 & 32 \\
\hline 2008.01.12 & 22.0 & & & & & & & & & & & & \\
\hline 2008.05 .24 & 23.5 & 2008.5 .26 & $<1.8 \sim 11$ & 1.8 & 2.4 & 0 & 0.0 & $<1.8 \sim 11$ & 1.8 & 2.7 & 0 & 0.0 & 32 \\
\hline 2008.06.08 & 14.0 & 2008.6 .10 & $<1.8 \sim 4.0$ & 1.8 & 2.3 & 0 & 0.0 & $<1.8 \sim 2.0$ & $<1.8$ & 1.8 & 0 & 0.0 & 32 \\
\hline 2009.03 .16 & 30.5 & 2009.03 .13 & $<1.8 \sim 4.5$ & 1.9 & 2.6 & 0 & 0.0 & $<1.8 \sim 1.8$ & $<1.8$ & $<1.8$ & 0 & 0.0 & 32 \\
\hline 2009.07 .15 & 74.5 & 20090720 & م 2402 & 287 & 1371 & 3 & 94 & & $41+2$ & 114 & 1 & 31 & 32 \\
\hline 2009.07 .16 & 119 & 2009.07 .20 & $2.0 \sim 240$ & 28.1 & $13 / .1$ & 3 & 9.4 & $<1.8 \sim / 9$ & 4.1 & 14.4 & 1 & 3.1 & 32 \\
\hline
\end{tabular}

${ }^{1} \mathrm{GM}$, Geometric Mean.

${ }^{2} 90$ th, The estimated 90 th percentile.

중에서 시료 채취 전날에 강우가 발생했던 시기에 채취한 시료 에서 분변계대장균수의 기준치를 초과하였다고 보고한 것으로 보아 패류의 위생학적 성상에 강우가 가장 크게 영향 을 미치는 요인이라고 평가할 수 있다. 이상의 결과로 보아 강진만 해역에서 생산되는 패류는 유럽연합의 $\mathrm{A}$ 등급 해역의 위생관리 기준에 부합되는 것으로 확인되었다.

강우에 따른 강진만 해역의 세균학적 수질변화

강우 발생에 따른 강진만 해역의 세균학적 수질변화를 알아 보기 위하여 위생조사 전 강우 발생량과 발생시점에 따른 해역의 수질변화를 Table 6에 나타내었다. 매월 1회, 3년간 36 회의 조사를 실시하였으며 조사 3 일전까지 $10 \mathrm{~mm}$ 이상의 강우가 발생한 횟수는 총 8회였으며 2007년 9월과 2009년 7월에 발생한 강우에 의하여 분변계대장균수의 기준치를 초
과하여 검출되었다. 2007년 9월에는 조사 3 일전 $76.0 \mathrm{~mm}$ 및 조사 2 일전 $91.5 \mathrm{~mm}$ 의 강우가 집중되어 지정해역 내에 위치한 32 개 전 조사지점에서 분변계대장균수가 $43 \mathrm{MPN} / 100 \mathrm{~mL}$ 을 초과하였는데 조사당일 강진만 해역 해수의 평균염분이 10.15 $\mathrm{psu}$ 로 나타난 것으로 보아 육상에서 담수와 함께 오염원이 대량으로 유입이 되어 전 조사지점에서 기준치를 초과 검출된 것으로 사료된다. 그러나 조사 5일전 $74.5 \mathrm{~mm}$ 및 조사 4일전 $119 \mathrm{~mm}$ 의 집중강우가 발생했던 2009년 7월 조사에서는 강진 만 상부해역에 위치한 17 번 지점에서만 분변계대장균수의 값이 $79 \mathrm{MPN} / 100 \mathrm{~mL}$ 으로 기준치를 초과하였을 뿐 그 외에 조사지점에서는 분변계대장균 수의 범위가 <1.8 33 MPN/100 $\mathrm{mL}$ 으로 나타났다.

$\mathrm{Ha}$ et al. (2009)도 2007년 7월에 조사 전날 $39.5 \mathrm{~mm}$ 및 조사일 시료채취 전까지 $52.0 \mathrm{~mm}$ 의 강우가 집중되었을 때 
한산.거제만해역 지정해역 내 21개 조사지점 중 9개 지점 (42.9\%)에서 기준치를 초과하였다고, Chang et al. (1998)도 득량만 해수의 세균학적 수질에 관한 연구에서 조사 2일전부 터 $93 \mathrm{~mm}$ 의 강우가 있었던 6월 $(23.1 \%)$ 에 강우가 없었던 7월 (3.8\%)보다 증가하였다고, Song et al. (2008)은 서해안 태안해역에서 조사 전날 $65.4 \mathrm{~mm}$ 의 강우발생으로 인하여 해 수의 세균학적 수질이 악화되었다고 보고하였다. 이상의 결과 를 종합해 볼때 강우 발생량보다는 강우 발생시점이 해역의 수질에 가장 큰 영향을 미치는 것으로 확인되었다.

그리고 조사 2일전 $41.0 \mathrm{~mm}$ 및 조사 1일전 $37.0 \mathrm{~mm}$ 강우가 발생한 2007년 7월 조사에서는 기준치를 초과하여 검출된 조사지점은 없었으며 분변계대장균수의 범위가 <1.8 33 $\mathrm{MPN} / 100 \mathrm{~mL}$ 으로 양호한 위생상태를 나타내었으며, 또한 조 사 2일전 $23.0 \mathrm{~mm}$ 와 $23.5 \mathrm{~mm}$ 강우가 있었던 2007년 4월과 2008년 5월에 지정해역 해수의 분변계대장균수의 범위는 각 각 <1.8 4.0 MPN/100 mL 및 <1.8 11 MPN/100 mL으로 아주 양호한 위생상태를 나타내고 있었다. 이것으로 보아 조사 전 날 $30.0 \mathrm{~mm}$ 정도의 강우가 발생하여도 강진만 지정해역 해수 는 우리나라 및 미국의 허가해역 수질기준 부합할 것으로 추정되며, 이는 현재 강진만 해역에 설정되어 있는 완충해역 이 적절하게 설정되어 있다고 평가할 수 있다.

그러나 최근 지구온난화 등과 같은 기후변화로 인하여 예전 에 볼 수 없었던 국지성 집중호우가 자주 발생하고 있어 갑작 스러운 많은 비가 짧은 시간에 내리면 강진만 패류생산해역의 위생학적 안전성이 위협 받을 수 있으며 또한 배수유역의 면적, 인구현황, 강우량 및 표층수의 유입량 등이 해역의 수질 에 영향을 미치는 요소로 알려져 있기 때문에 강진만 해역의 배수유역에 산재되어 있는 오염원량과 강우 발생등급에 따라 오염원 유입량이 해역에 미치는 영향과 이들 상관관계에 대한 추가적인 연구가 필요할 것으로 사료된다.

$$
\text { 사 사 }
$$

본 연구는 국립수산과학원 (수출패류 생산해역 및 수산물 위생조사, RP-2010-FS-011)의 지원에 의해 수행되었으며 이 에 감사드립니다.

\section{참고문헌}

APHA. 1970. Recommended procedures for the examination of seawater and shellfish, 4th ed., Americal Public Health Association, Washington, D.C., U.S.A., 1-47.

Chang DS, Jeong ET, Yu HS, Lee EW and Lim SM. 1998. Bacteriological quality of sea water in Deukryang Bay, Korea. J Kor Fish Soc 31, 77-81.

Cliver, DO. 1988. Virus transmission via foods. Food Technol 42, 241-248.

European Commission. 2004. Regulation (EC) No $854 / 2004$ of the European Parliament and of the
Council of 29 April 2004 laying down specific rules for the organisation of official controls on products of animal origin intended for human consumption. Off J Eur Communities L155, 206-321.

European Commission. 2005. Commission Regulation (EC) No 2073/2005 of 15 November 2005 on microbiological criteria for foodstuffs. Off $\mathrm{J}$ Eur Union L338, 1-23.

Feldhusen F. 2000. The role of seafood in bacterial foodborne diseases. Microbes Infect 2, 1651-1660.

Grimes DJ. 1991. Ecology of estuarine bacteria capable of causing human disease: A review. Estuaries 14, 345-360.

Ha KS, Shim HK, Yoo HD, Kim JH and Lee TS. 2009. Evaluation of the bacteriological quality of a shellfish growing area in Hansan - Geojeman, korea. Kor J Fish Aquat Sci 42, 449-455.

Kim SJ. 1975. Sanitary studies of oysters and growing areas in the south coast of Korea. Bull. Fisheries Research \& Development Agency 14, 1-79.

Kwon JY, Park KBW, Song KC, Lee JH, Park JH, Kim JD and Son KT. 2007. Evaluation of the bacteriological quality of a shellfish-growing area in Kamak bay, Kor J Fish Sci Technol 11, 7-14.

ISO (International Organization for Standardization). 2005. ISO/TS 16649-3. Microbiology of Food and Animal Feeding Stuffs. Horizontal Method for the Enumeration of Beta-Glucuronidse-positive Escherichia coli. Part 3: Most Probable Number Technique Using 5-Bromo-4-chloro-3-indolyl-beta-D-glucuronide. ISO, 1-8.

Legnani P, Leoni E, Lev D, Rossi R, Villa GC and Bisbini P. 1998. Distribution of indicator bacteria and bacteriophages in shellfish and shellfish growing waters. J Appl Microbiol 85, 790-798.

Lipp EK and JB Rose. 1997. The role of seafood in the foodbrone disease in the United States of America. Rev Sci Technol Off Int Epizoot 16, 620-640.

MOMAF. 2002. Sanitary criteria of producing · processing facilities and sea water area for fisheries products. The notification of the Ministry of Maritime Affairs \& Fisheries Article, 2002-74.

Potasman I, Paz A and Odeh M. 2002. Infectious outbreaks associated with bivalve shellfish consumption: A worldwide perspective. Clin Infect Dis 35, 921-928.

Shim KB, Ha KS, Yoo HD, Kim JH and Lee TS. 2009. Evaluation of the bacteriological safety for the shellfish growing area in Jaranman - Saryangdo area, Korea. Kor J Fish Sci 42, 442-448. 
Song KC, Lee DS, Shim KB, Lim CW, Mog JS, Byun HS, Park YJ and Cho KC. 2008. Evaluation of bacteriological safety for the shellfish growing waters in Taean area. Kor J Fish Aquat Sci 41, 155-162.

U.S. Food and Drug Administration. 2007. National Shellfish Sanitation Program, Guide for the control of molluscan shellfish, Model ordinance. Retrieved from http://www.fda.gov/Food/FoodSafety/Product-Specif
icInformation/Seafood/FederalState Programs/ National Shellfish Sanitation Program/ defaulthtm.

2010년 9월 2일 접수
2010년 10월 20일 수정
2010년 12월 3일 수리

2010년 12월 3일 수리 